\title{
Aplikasi Manajemen Proyek Konstruksi Dengan Metode Critical Path dan Earned Value Management
}

\author{
Eka Budhy Prasetya \\ Fakultas Teknik, Jurusan Teknik Informatika, Universitas Muhammadiyah Jakarta \\ eka.budhy@ftumj.co.id
}

\begin{abstract}
Abstrak
Mengerjakan proyek tepat waktu dan biaya merupakan target setiap perusahaan kontraktor. Namun pada kenyataannya hal tersebut masih sangat sulit dilakukan. Berbagai hal seperti sistem yang berjalan, human error serta teknologi yang dipakai mempengaruhi tingkat keberhasilan pengerjaan proyek. Dengan menggunakan metode critical path bisa diketahui durasi pengerjaan proyek serta aktifitas yang berada dijalur kritis. Metode ini berfungsi untuk pengendalian waktu yang dapat dimonitor secara berkala. Metode earned value management berfungsi dalam pengendalian biaya. Metode ini terdiri dari budget cost for work schedule (BCWS) yaitu anggaran rencan, budget cost for work performed (BCWP) yaitu laporan perkembangan proyek, dan actual cost for work performed (ACWP) yaitu laporan pengeluaran proyek. Dengan ketiga parameter tersebut dapat diketahui presentase rencana anggaran, presentase perkembangan proyek serta presentase pengeluaran proyek. Sehingga dapat segera ketahui jika terjadi over budget maupun jika terjadi keterlambatan pengerjaan proyek. Dalam Perancangan sistem aplikasi manajemen proyek ini menggunakan aplikasi php dan Mysql.
\end{abstract}

Kata kunci : human error, critical path, earned value management, budget cost for work schedule, budget cost for work performed, actual cost for work performed

\begin{abstract}
Working Project on time and cost is the target of each contractor. But in fact it is still very difficult. Various things like the system running, human error as well as the technology used affect the success rate of project. By using the critical path method can be known as well as the duration of the project was on track critical activities. This method serves to control time can be monitored regularly. Method of earned value management function is controlling costs. This method consists of a budget cost for work schedule (BCWS), namely the budget plan, budget cost for work performed $(B C W P)$ is a project progress report, and the actual cost for work performed (ACWP) that project expenditure reports. With all three of these parameters can be determined percentage of the budget plan, the percentage of development projects as well as the percentage of project expenditures. So it can immediately know if there is over budget or in case of delays in the project. In creation this project management application system design using php and Mysql application.
\end{abstract}

Keywords: human error, critical path, earned value management, budget cost for work schedule, budget cost for work performed, actual cost for work performed

\section{PENDAHULUAN}

Manajemen sebagai ilmu mengelola suatu kegiatan yang skalanya dapat bersifat kecil atau bahkan sangat besar, mempunyai ukuran tersendiri pada hasil akhir [1]. Mengerjakan proyek tepat waktu sesuai dengan biaya, lingkup pekerjaan, serta mutu yang sudah ditetapkan menjadi target setiap perusahaan. Namun pada kenyataannya hal tersebut sangat sulit dilakukan dari semua proyek yang pernah dikerjakan Perusahaan semuanya mengalami keterlambatan bahkan keterlambatan bisa mencapai 2 sampai 3 bulan.
Beberapa kendala seperti tingkat SDM , sistem yang yang berjalan serta teknologi yang dipakai sangat menentukan kecepatan pengerjaan suatu proyek. Belum lagi faktor cuaca, kondisi lapangan yang mungkin masih berupa hutan, atau sawah serta jalan menuju lokasi proyek sedikit banyak mempengaruhi tingkat kecepatan dalam pengerjaan proyek. Banyak aktivitas manusia yang berhubungan dengan system informasi [2].

Keterlambatan proyek akan berdampak pada pembengkakan biaya yang tidak sedikit, belum lagi jika ada sanksi berupa surat keputusan daftar hitam / black list sehingga tidak bisa mengikuti tender dari pemerintah selama 2 tahun. Untuk itu keterlambatan proyek harus dikurangi atau bahkan dihilangkan. 
RESISTOR (elektRonika kEndali telekomunikaSI tenaga liSTrik kOmputeR) Vol. 1 No. 2 e-ISSN : 2621-9700, p-ISSN : 2654-2684

Berdasarkan latar belakang masalah yang ada maka penulis mencoba membuat penelitian dengan judul "Aplikasi Manajemen Proyek Konstruksi Dengan Metode Critical Path Dan Earned Value Management Berbasis Web.

Berdasarkan identifikasi masalah yang ada, kondisi manajemen proyek di Perusahaan dapat dijelaskan sebagai berikut :

1. Jumlah karyawan yang ada berbanding terbalik dengan banyaknya beban kerja.

2. Dari seluruh proyek yang pernah dikerjakan semuanya mengalami keterlambatan.

3. Dari semua proyek yang pernah dikerjakan jumlah biaya yang dikeluarkan melebihi total biaya yang sudah dianggarkan.

4. Belum ada aplikasi terpadu untuk mengontrol dan mengendalikan proyek secara langsung dari segi waktu dan biaya. berikut

Rumusan masalah yang ada adalah sebagai

1. Bagaimana membuat aplikasi yang mampu menampilkan jadwal pengerjaan proyek.

2. Bagaimana membuat aplikasi yang mampu memberikan informasi mengenai batas toleransi keterlambatan sebuah pekerjaan yang tidak mempengaruhi tenggang waktu keseluruhan proyek.

3. Bagaimana merancang aplikasi yang mampu menampilkan biaya yang sudah dikeluarkan dengan progress pekerjaan yang sudah selesai dikerjakan.

Agar masalah yang diteliti tidak menyimpang dan keluar dari tema penelitian, maka diperlukan suatu pembatas masalah. Adapun batasan-batasan masalah tersebut adalah sebagai berikut:

1. Seluruh data yang digunakan berasal dari Perusahaan pada proyek pembangunan rumah khusus TNI wilayah Banten.

2. Aplikasi yang dikembangkan adalah aplikasi manajemen proyek yang berfungsi untuk membuat jadwal pengerjaan proyek dengan menggunakan metode critical path yaitu dengan melakukan perhitungan maju dan perhitungan mundur.

3. Penggunaan metode earned value management untuk pengendalian biaya.

4. Aplikasi yang akan dibuat adalah aplikasi berbasis web yang dikembangkan menggunakan PHP dan MySQL.

Tujuan dalam penulisan penelitian ini adalah untuk membangun sebuah aplikasi yang dapat digunakan untuk mempermudah manajer proyek dalam melakukan manajemen waktu dan biaya dalam suatu proyek.
Metodologi penelitian yang digunakan dalam Penelitian ini adalah sebagai berikut :

Untuk memperoleh data - data yang diperlukan dalam penelitian tugas akihr ini, dilakukan pengumpulan data dengan langkah langkah sebagai berikut :

\section{a. Observasi}

Metode observasi yang dilakukan yaitu dengan cara mengamati langsung tim manajemen proyek Perusahaan dalam membuat perencanaan proyek dan menjalankan aktifitas manajemen proyek.

b. Wawancara

Dilakukan dengan mangajukan pertanyaan secara langsung kepada anggota tim manajemen dan manajer proyek mengenai sistem manajemen proyek yang dilakukan.

\section{c. Studi Pustaka}

Metode pengumpulan data dalam studi pustaka, dilakukan dengan studi banding baik dari buku, modul dan catatan perkuliahan yang terkait dengan analisa perencanaan sistem informasi, program tentang web, manajemen proyek, metode jalur kritis serta metode earned value. Tujuan yang hendak dicapai atau diinginkan dalam merekayasa perangkat lunak adalah menghasilkan suatu produk perangkat lunak yang baik yaitu perangkat lunak yang mudah digunakan, dirawat, dapat diandalkan, bekerja secara efisien dan mempunyai antar muka pemakai yang baik dan juga bila ditinjau dari segi biaya sangat ekonomis dan efisien[3], [4]. Tujuan pembuatan bahasa pemrograman Java adalah untuk meningkatkan kemampuan bahasa pemrogramman c++ yang telah ada sebelumnya [5]. Untuk menjaga agar proses produksi tersebut dapat berjalan dengan baik, diperlukan metode pengendalian proses produksi yang baik [6].

a. Analisis Sistem Berjalan

Dilakukan dengan menggambarkan prosedur yang berjalan selama ini dalam proses manajemen proyek di perusahaan.

b. Perencanaan

Dalam penelitian ini direncanakan pembuatan suatu sistem manajemen proyek menggunakan metode jalur kritis dan earned value untuk mengetahui presentase pengerjaan proyek dan presentase pengeluaran proyek.

\section{c. c. Analisis Kebutuhan}

Untuk meneliti semua kebutuhan dalam pembuatan aplikasi yang akan dibuat melalui analisis pada sistem yang sudah berjalan untuk mencari data yang dibutuhkan, studi pustaka, wawancara dengan pihak terkait lalu menggambarkan hasil analisis tersebut ke dalam 
sistem pemodelan dengan menggunakan UML (unified modeling language).

d. Desain

Desain sistem yang akan dibuat dan dikembangkan adalah dengan menggunakan use case diagram, menentukan kardinalitas hubungan database dengan membuat ERD (Entity Relationship Diagram), Desain antarmuka grafis yang mudah dipahami oleh pengguna. Sedangkan desain programnya dibuat dengan menggunakan Adobe Dream Weaver 6 yang didukung oleh Mysql.

e. Pengujian Aplikasi

Pada tahap ini ouput dari aplikasi yang dihasilkan apakah sesuai dengan apa yang diharapkan serta menguji kemampuan sistem aplikasi yang telah dibuat.

\section{METODE}

Manajemen proyek adalah penerapan ilmu pegetahuan, keahlian, dan ketrampilan, cara teknis yang terbaik dengan sumber daya yang terbatas, untuk mencapai sasaran dan tujuan yang telah ditentukan agar mendapatkan hasil yang optimal dalam hal kinerja biaya, mutu dan waktu, serta keselamatan kerja [1].

Metode jalur kritis atau critical path method (CPM) adalah sebuah teknik pemodelan proyek yang dikembangkan oleh Morgan R. Walker dari Dupont dan James E.Kelley dari Remington Rand di akhir tahun 1950. Metode ini mampu mengidentiikasi jalur kritis pada sekumpulan aktifitas yang telah ditentukan ketergantungan antar aktifitasnya.

Aktifitas adalah sebuah tugas spesifik yang memiliki satu hasil yang dapat diukur yang memiliki durasi pengerjaannya. Jalur kritis adalah sekumpulan aktifitas yang saling bergantung yang harus selesai sesuai dengan waktu yang direncanakan karena jika tidak maka keseluruhan waktu pengerjaan proyek akan terlambat.

Tahapan yang dilakukan dalam metode jalur kritis adalah sebagai berikut:

a. Tentukan aktifitas - aktifitas proyek dan identifikasi ketergantungan (dependency) antar aktifitas tersebut. Aktifitas yang hanya dapat dilakukan setelah aktifitas tertentu selesai dilakukan disebut predecessor dan aktifitas yang menjadi prasyarat itu disebut successor.

b. Tentukan durasi (duration) untuk setiap aktifitas, setelah itu buat node untuk memulai lalu hubungkan dengan aktifitas pertama atau aktifitas yang tidak memiliki predecessor. Kemudian hubungkan aktifitas - aktifitas tersebut dengan aktifitas yang bergantung kepadanya atau successor dan seterusnya hingga ke node finish. Aktifitas tanpa predecessor dihubungkan dengan node start. Aktifitas tanpa successor dihubungkan dengan node finish.

c. Tentukan waktu tercepat untuk memulai (early start), waktu tercepat untuk selesai (early finish) serta waktu paling akhir untuk emulai dan selesai tanpa mengubah keseluruhan waktu proyek (late start dan late finish).

Early start adalah waktu tercepat untuk sebuah aktifitas dapat dimulai setelahpredecessornya selesai dilakukan. Early finish adalah waktu tercepat aktifitastersebut selesai, dalam hal ini berarti early start + Duration. Menentukan early start dimulai dari start lalu aktifitas paling awal. Early Start untuk aktifitas pertama (yang tidak memiliki predecessor) adalah 0 dan early finishnya adalah $0+$ duration aktifitas tersebut. Mencari ES dan EF dimulai dari start dan sucessornya. Jika ada dua aktifitas sebelum sebuah sucecessor, maka diambil EF yang paling besar.

Sedangkan late start (LS) adalah waktu yang paling lambat sebuah aktifitas dapat dimulai tanpa mengubah target waktu akhir dari keseluruhan proyek. Sementara late finish (LF) adalah waktu yang paling lambat sebuah aktifitas harus selesai tanpa mengubah target waktu akhir. LS adalah LF .duration. jika saat mencari ES dan EF dimulai dari start dan dirunut hingga ke aktifitas terakhir sebelum finish ( aktifitas yang tidak memiliki successor), pada LS dan LF dirunut dari aktifitas terakhir mundur hingga start karena patokannya adalah target waktu terakhir dari proyek. Sehingga LF untuk aktifitas terakhir adalah waktu keseluruhan proyek akan berakhir, dan LS nya adalah LF - duration. LS dari sebuah aktifitas adalah LF untuk aktifitas predecessornya. Jika ada dua aktifitas sebelum sebuah predecessor, maka diambil LS yang paling kecil.

Float atau Slack adalah toleransi waktu telat sebuah aktifitas untuk dimulai dari early start (LS) tetapi tidak mengubah tenggang waktu keseluruhan proyek. Aktifitas - aktifitas pada jalur kritis memiliki Float atau Slack o. 
RESISTOR (elektRonika kEndali telekomunikaSI tenaga liSTrik kOmputeR) Vol. 1 No. 2 e-ISSN : 2621-9700, p-ISSN : 2654-2684

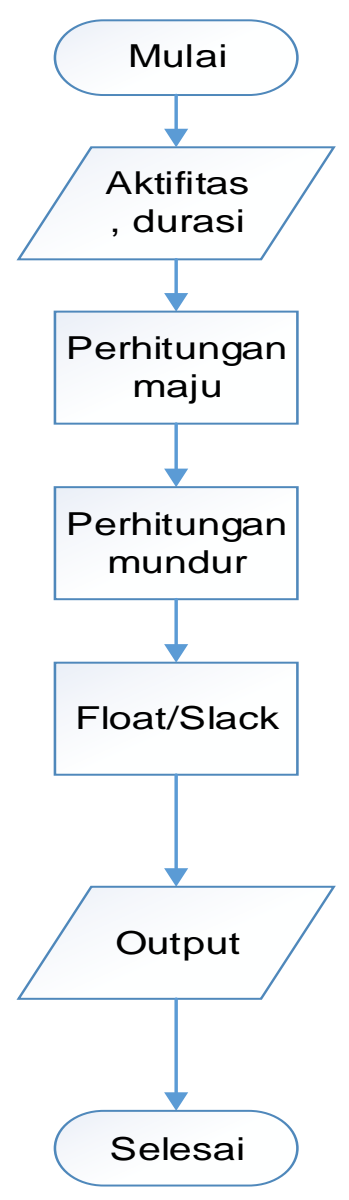

Gambar 1. Diagram alir perhitungan dengan metode CPM [7].

Pada perhitungan maju, perhitungan bergerak dari initial event menuju terminal event. Maksudnya ialah menghitung saat yang paling cepat terjadinya events dan saat paling cepat dimulainya serta diselesaikannya aktifitas-aktifitas (TE, ES, dan EF).

Waktu kelaksanaan (duration) kegiatan A adalah 2 hari sehingga saat tercepat diselesaikannya aktifitas A adalah pada hari kedua atau $\operatorname{EF}(0,1)$ $=2$. Karena aktifitas $\mathrm{A}$ ini adalah satursatunya aktifitas yang memasuki node 1 , maka saat tercepat terjadinya event nomor 1 juga pada hari kedua, atau

$\mathrm{TE}_{(1)}=2$. Maka masukkan angka 2 ke dalam ruang kiri node 1.

$\mathrm{TE}_{(2)}=\mathrm{EF}_{(1,2)}=\mathrm{EF}_{(0,1)}+$ duration $=\mathrm{TE}_{(1)}$ $+6=2+6=8$

$\mathrm{TE}(3)=\mathrm{EF}(2,3)=\mathrm{EF}(1,2)+$ duration $=\mathrm{TE}(2)$

$+5=8+5=13$

$\mathrm{TE}(4)=\mathrm{EF}_{(2,4)}=\mathrm{EF}(1,2)+$ duration $=\mathrm{TE}(2)$

$+4=8+4=12$

Node 5 merupakan merge event, $\mathrm{EF}(3,5)=$ $13+0=13$ dan $\mathrm{EF}_{(4,5)}=12+0=12$. Maka
$\mathrm{TE}(5)=$ maks $(13,12)=13$, dan masukan angka 13 pada ruang kiri bawah dari node 4

$\mathrm{TE}(6)=\mathrm{EF}(5,6)=\mathrm{EF}(3,5)+$ duration $=\mathrm{TE}(5)$

$+9=13+9=22$

$\mathrm{TE}(7)=\mathrm{EF}(5,7)=\mathrm{EF}(3,5)+$ duration $=\mathrm{TE}(5)$

$+7=13+7=20$

$\mathrm{TE}(8)=\mathrm{EF}(6,8)=\mathrm{EF}(5,6)+$ duration $=\mathrm{TE}(6)$

$+6=22+6=28$

$\mathrm{TE}(9)=\mathrm{EF}(8,9)=\mathrm{EF}(6,8)+$ duration $=\mathrm{TE}(8)$

$+9=28+9=37$

Node 10 merupakan merge event, $\mathrm{EF}(9,10)=$ $37+4=41$ dan $\operatorname{EF}(7,10)=20+5=25$. Maka $\mathrm{TE}(10)=$ maks $(41,25)=41$, dan masukan angka 41 pada ruang kiri bawah dari node 10 .

$\mathrm{TE}_{(11)}=\mathrm{EF}_{(10,11)}=\mathrm{EF}(9,10)+$ duration = $\mathrm{TE}(10)+2=41+2=43$

Pada perhitungan mundur, perhitungan bergerak dari dari terminal event menuju ke initial event. Tujuannya ialah untuk menghitung saat paling lambat terjadinya events dan saat paling lambat dimulainya dan diselesaikannya aktifitasaktifitas (TL, LS, dan LF).

Dari hasil perhitungan maju diperoleh $\mathrm{TE}(11)=43$, sehingga dengan sendirinya $\mathrm{TL}(11)$ $=43$. Masukkan angka 43 pada ruang kanan bawah dari node 11. Aktifitas I dapat diselesaikan paling lambat pada hari ke-43 dengan duration 2 hari, maka aktifitas I dapat dimulai pelaksanaannya paling lambat setelah hari

$$
\begin{aligned}
& \text { ke-43- } 2=41 \text { sehingga } \operatorname{TL}(10)=41 \\
& \operatorname{TL}(9)=41-\text { duration }=41-4=37 \\
& \operatorname{TL}(8)=37-\text { duration }=37-9=28 \\
& \operatorname{TL}(7)=41-\text { duration }=41-5=36 \\
& \operatorname{TL}(6)=28-\text { duration }=28-6=22
\end{aligned}
$$

Node 5 merupakan burst event, $\mathrm{LS}_{(5,6)}=22$ $-9=13$ dan $\operatorname{EF}(5,7)=36-7=29$. Maka TL(5) $=\min (13,29)=13$, dan masukan angka 13 pada ruang kiri bawah dari node 5 .

$$
\begin{aligned}
& \mathrm{TL}(4)=13-\text { duration }=13-0=13 \\
& \operatorname{TL}(3)=13-\text { duration }=13-0=13
\end{aligned}
$$

Node 2 merupakan burst event, $\operatorname{LS}_{(2,3)}=13$ $-5=8$ dan $\mathrm{EF}(2,4)=13-4=9$. Maka TL(2) $=$ min $(8,9)=8$, dan masukan angka 8 pada ruang kiri bawah dari node 2

$$
\begin{aligned}
& \mathrm{TL}(1)=8-\text { duration }=8-6=2 \\
& \mathrm{TL}(0)=2-\text { duration }=2-2=0
\end{aligned}
$$

Setelah perhitungan maju dan perhitungan mundur selesai dilakukan, maka berikutnya dilakukan perhitungan kelonggaran waktu (float/slack) dari aktifitas (i,j), yang terdiri atas total float dan free float. Total float dihitung dengan cara mencari selisih antara saat paling 
RESISTOR (elektRonika kEndali telekomunikaSI tenaga liSTrik kOmputeR) Vol. 1 No. 2 e-ISSN : 2621-9700, p-ISSN : 2654-2684

lambat diselesaikannya aktifitas dengan saat paling cepat diselesaikannya aktifitas (LF - ES). Sedangkan free float aktifitas(i,j) dihitung dengan cara mencari selisih antara saat tercepat terjadinya event di ujung aktifitas dengan saat tercepat diselesaikannya aktifitas $(\mathrm{i}, \mathrm{j})$ tersebut.

Total float dapat dihitung dengan menggunakan rumus $\mathrm{S}_{(\mathrm{i}, \mathrm{j})}=\mathrm{TL}(\mathrm{j})-\mathrm{TE}(\mathrm{i})-\mathrm{t}(\mathrm{i}, \mathrm{j})$ Free float dapat dihitung dengan menggunakan rumus $\mathrm{SF}(\mathrm{i}, \mathrm{j})=\mathrm{TE}(\mathrm{j})-\mathrm{TE}(\mathrm{i})$ $-\mathrm{t}(\mathrm{i}, \mathrm{j})$

Suatu aktifitas yang tidak mempunyai kelonggaran (float) disebut aktifitas kritis. Dengan kata lain, aktifitas kritis mempunyai $\mathrm{S}=\mathrm{SF}=0$. Pada kasus di atas, aktifitas kritisnya adalah aktifitasaktifitas A, B, C, E, F, H, I, K dan L. Akrivitasaktifitas kritis ini akan membentuk lintasan kritis yang biasanya dimulai dari initial event sampai ke terminal event. Lintasan kritisnya adalah lintasan yang melalui node $0,1,2,3,5,6,8,9,10$ dan 11 . Biasanya pada network digambarkan sebagai garis tebal sebagai berikut:

Tabel 1. Time-Chart Pelaksanaan Proyek [7].

\begin{tabular}{|c|c|c|c|c|c|c|c|c|}
\hline \multirow[t]{3}{*}{$\begin{array}{l}\text { Kegia } \\
\tan \end{array}$} & \multirow[t]{3}{*}{$\begin{array}{l}\text { Pend } \\
\text { ahulu }\end{array}$} & \multirow[t]{3}{*}{$\begin{array}{l}\text { Dura } \\
\text { si }\end{array}$} & \multicolumn{2}{|c|}{$\begin{array}{l}\text { Paling } \\
\text { Cepat }\end{array}$} & \multicolumn{2}{|c|}{$\begin{array}{l}\text { Paling } \\
\text { Lambat }\end{array}$} & \multirow{3}{*}{$\begin{array}{c}\text { Tota } \\
1 \\
\text { float } \\
S\end{array}$} & \multirow{3}{*}{$\begin{array}{l}\mathrm{Fr} \\
\mathrm{ee} \\
\mathrm{fl} \\
\mathrm{oa} \\
\mathrm{t} \\
\mathrm{SF}\end{array}$} \\
\hline & & & $M$ & Sel & Mula & Sel & & \\
\hline & & & $\begin{array}{l}E \\
S\end{array}$ & $\begin{array}{l}E \\
F\end{array}$ & $\begin{array}{l}\mathrm{L} \\
\mathrm{S}\end{array}$ & , & & \\
\hline A & & 2 & d & 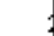 & 0 & 1 & 0 & 0 \\
\hline$B$ & & 6 & 3 & 8 & 2 & 8 & 0 & \\
\hline$c$ & & 5 & g & 1 & 8 & 1 & 0 & +j \\
\hline $\mathrm{D}$ & & 4 & q & & 8 & & 1 & 0 \\
\hline & & & & 1 & & 1 & & 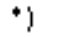 \\
\hline & & 0 & 1 & 2 & 1 & 3 & 0 & \\
\hline$=$ & & & 3 & & 3 & & & 1 \\
\hline & & 9 & & 1 & & 1 & 0 & \\
\hline $\mathrm{G}$ & & 7 & $\begin{array}{l}1 \\
3\end{array}$ & & $\begin{array}{l}1 \\
3\end{array}$ & 3 & 16 & 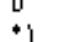 \\
\hline E & & & & 2 & & 2 & & \\
\hline $\mathrm{H}$ & & 6 & 1 & 2 & 1 & 2 & 0 & 0 \\
\hline$F$ & & & 3 & & 3 & & & $*$ \\
\hline נ & & 9 & 2 & $\begin{array}{l}2 \\
0\end{array}$ & 2 & $\begin{array}{l}3 \\
6\end{array}$ & 0 & 2 \\
\hline$k$ & & 5 & 2 & 2 & 2 & & 16 & \\
\hline $\mathrm{L}$ & & 4 & 2 & 8 & 2 & 8 & 0 & $\dot{0}$ \\
\hline
\end{tabular}
Aktifitas kritis
:A ? B ? C ? E ? F ?

$\mathrm{H}$ ? I ? K? L

Waktu Pelaksanaan : $2+6+5+0+9+6+$

$9+4+2=43$

Flemming dan Koppelman yang dikutip oleh [8] menjelaskan konsep earned value dibandingkan manajemen biaya tradisional. Seperti dijelaskan pada Gambar II.8.a, manajemen biaya tradisional hanya menyajikan dua dimensi saja yaitu hubungan yang sederhana antara biaya aktual dengan biaya rencana. Dengan manajemen biaya tradisional, status kinerja tidak dapat diketahui. Sebaliknya, konsep earned value memberikan dimensi yang ketiga selain biaya aktual dan biaya rencana. Dimensi yang ketiga ini adalah besarnya pekerjaan secara fisik yang telah diselesaikan atau disebut earned value / percent complete. Dengan adanya dimensi ketiga ini, seorang manajer proyek akan dapat lebih memahami seberapa besar kinerja yang dihasilkan dari sejumlah biaya yang telah dikeluarkan

Ada tiga elemen dasar yang menjadi acuan dalam menganalisa kinerja dari proyek berdasarkan konsep earned value. Ketiga elemen tersebut adalah:

- BCWS (Budgeted Cost forWork Schedule) merupakan anggaran biaya yang dialokasikan berdasarkan rencana kerja yang telah disusun terhadap waktu. BCWS dihitung dari akumulasi anggaran biaya yang direncanakan untuk pekerjaan dalam periode tertentu. Dalam tabel pengolahan data, BCWS di dapat dengan menggunakan persamaan:

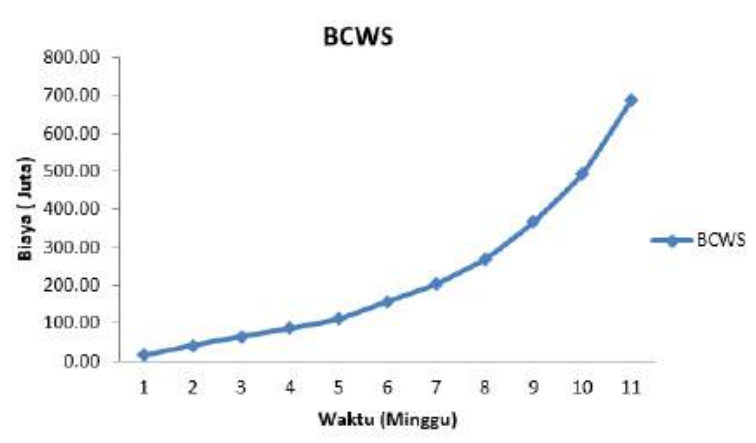

Gambar 2. Contoh Grafik BCWS [8].

- Budgeted Cost for Work Performed (BCWP) adalah nilai yang diterima dari penyelesaian pekerjaan selama periode waktu tertentu. BCWP inilah yang disebut earned value. BCWP ini dihitung berdasarkan akumulasi dari pekerjaanpekerjaan yang telah diselesaikan. Ada beberapa cara untuk menghitung BCWP diantaranya adalah: Fixed formula, Milestone weights, Milestone weights with percent complete, Unit complete, Percent complete, Level of effort. 
RESISTOR (elektRonika kEndali telekomunikaSI tenaga liSTrik kOmputeR) Vol. 1 No. 2 e-ISSN : 2621-9700, p-ISSN : 2654-2684

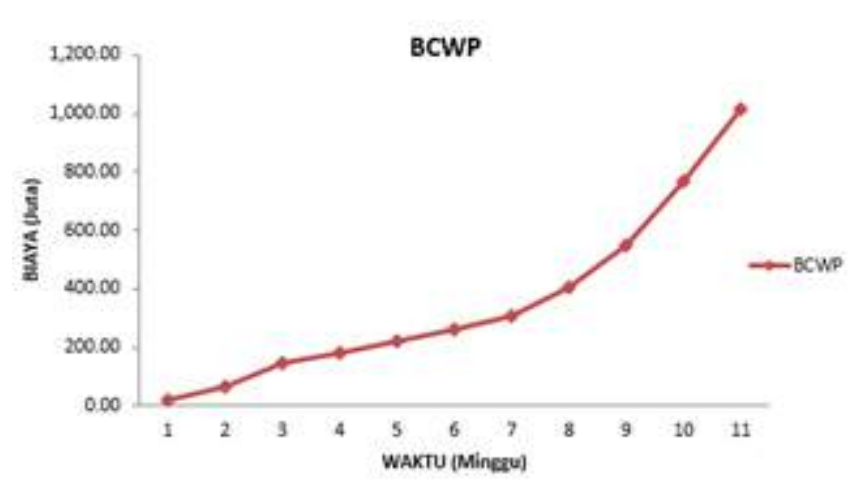

Gambar 3. Contoh Grafik BCWP [8].

- Actual Cost for Work Performed (ACWP) adalah representasi dari keseluruhan pengeluaran yang dikeluarkan untuk menyelesaikan pekerjaan dalam periode tertentu. ACWP dapat berupa komulatif hingga periode perhitungan kinerja atau jumlah biaya pengeluaran dalam periode waktu tertentu. Grafik ACWP merupakan jumlah biaya aktual dari pekerjaan yang telah dilaksanakan. Biaya ini diperoleh dari data-data akuntansi atau keuangan proyek pada tanggal pelaporan. Jadi, ACWP merupakan jumah aktual dari pengeluaran yang digunakan untuk melaksanakan pekerjaan pada kurun waktu tertentu. Ketiga indikator setelah dianalisis akan memberikan gambaran mengenai pencapaian jadwal dan anggaran

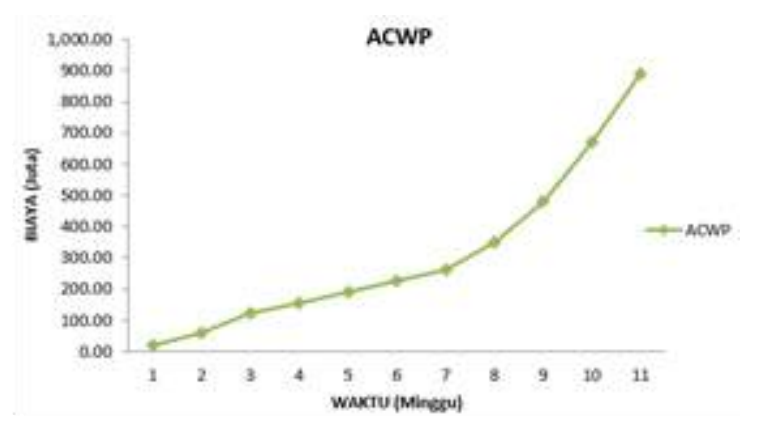

Gambar 4. Contoh Grafik ACWP [8].

Konsep dari metode EVM adalah membandingkan antara hasil dari BCWP yang merupakan laporan perkembangan pekerjaan proyek dan ACWP yaitu laporan pengeluaran proyek.

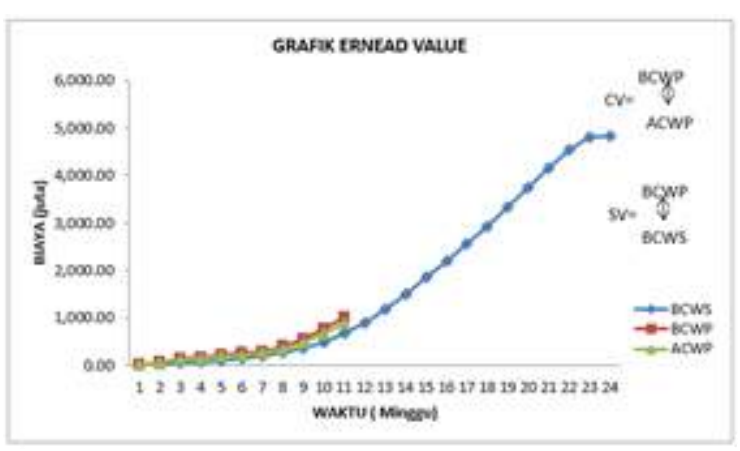

Gambar 5. Grafik Hasil Earned Value [8].

Sistem berjalan yang akan dianalisis adalah prosedur penjadwalan aktifitas proyek dan prosedur pengendalian proyek.

1. Prosedur penjadwalan proyek :

a. Pengendali proyek membuat jadwal proyek berupa kurva S sesuai permintaan dari owner.

b. Manajer proyek mengkoordinasi seluruh kegiatan di proyek sesuai dengan jadwal yang sudah dibuat oleh pengendali proyek.

2. Prosedur pengendalian proyek :

a. Pengendali proyek membuat rencana anggaran pelaksanaan proyek (RAPP).

b. Manajer proyek melakukan permintaan material, alat dan dana proyek.

c. Pengendali proyek mengecek setiap permintaan material, alat dan dana dari proyek manajer dengan anggaran dalam (RAPP).

d. Manajer proyek membuat laporan perkembangan proyek.

e. Pengendali proyek membuat laporan perkembangan proyek dan laporan RAPP yang telah dipakai ke jajaran direksi.

Dari penjelasan sistem berjalan di atas dapat digambarkan use case diagram sebagai berikut :

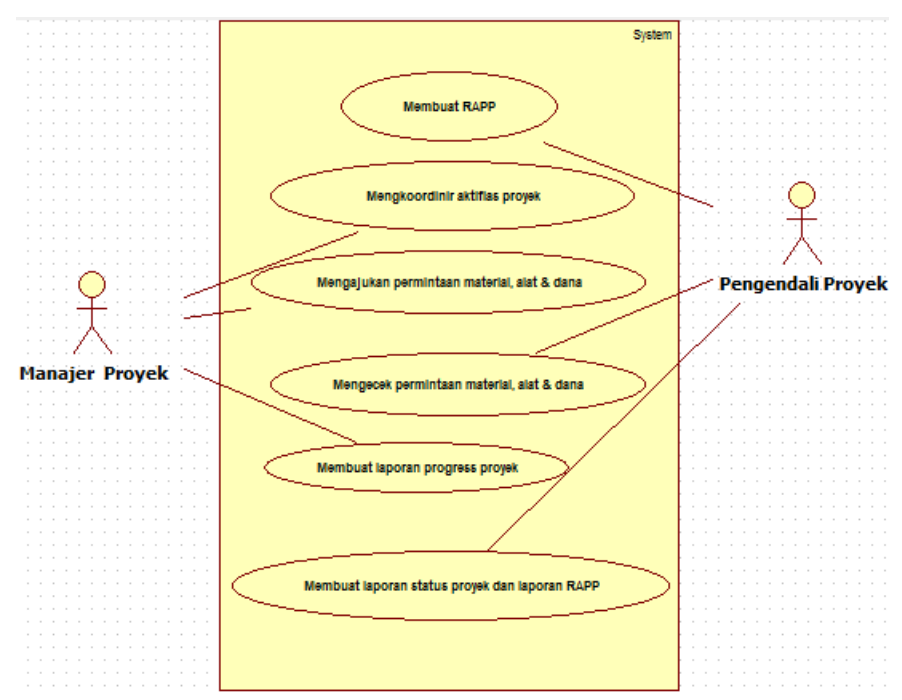

Gambar 6. Use case diagram sistem berjalan. 
RESISTOR (elektRonika kEndali telekomunikaSI tenaga liSTrik kOmputeR) Vol. 1 No. 2 e-ISSN : 2621-9700, p-ISSN : 2654-2684

Activity diagram menggambarkan urutan aktifitas mulai dari awal hingga akhir yang dapat menjelaskan adanya pilihan, iterasi atau aktifitas yang berjalan bersamaan. Berikut activity diagram sistem berjalan :

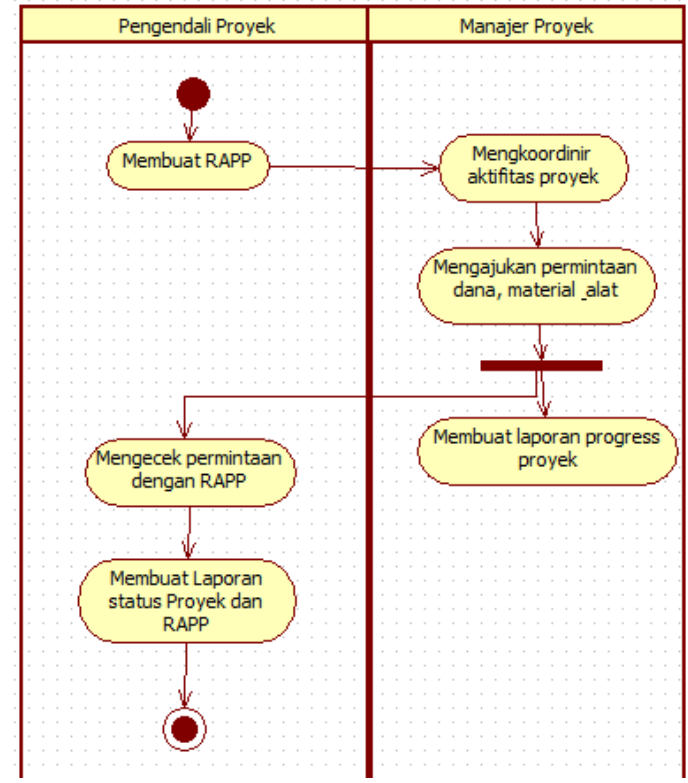

Gambar 7. Activity Diagram sistem berjalan.

Berdasarkan permasalahan yang ada dalam sistem manajemen proyek Perusahaan maka dibuat sistem usulan sebagai berikut :

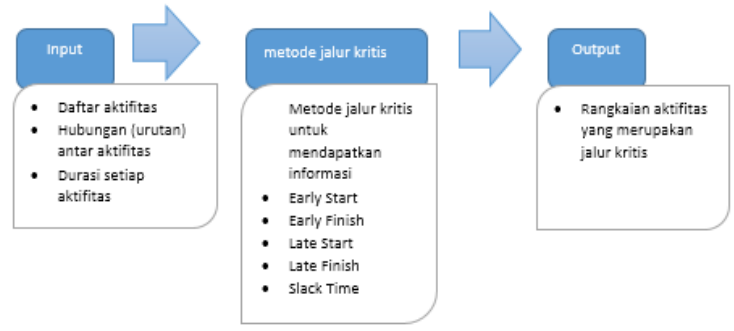

Gambar 8. Konsep Metode Jalur Kritis.

Seluruh data yang digunakan berasal dari Perusahaan dalam proyek rumah khusus TNI wilayah Banten. Adapun langkah - langkah dalam pembuatan penjadwalan proyek menggunakan metode jalur kritis adalah sebagai berikut :

Tabel 2. Penjadwalan Pengerjaan Proyek

\begin{tabular}{|c|c|c|c|c|}
\hline NO & $\begin{array}{c}\text { ITEM } \\
\text { PEKERJAAN }\end{array}$ & ID & $\begin{array}{l}\text { PEN } \\
\text { DAH } \\
\text { ULU }\end{array}$ & $\begin{array}{l}\text { DUR } \\
\text { ASI } \\
\text { (hari) }\end{array}$ \\
\hline 1 & Pekerjaan Persiapan & A & - & 7 \\
\hline 2 & $\begin{array}{l}\text { Pekerjaan Tanah, } \\
\text { Pondasi }\end{array}$ & B & A & 21 \\
\hline 3 & $\begin{array}{l}\text { Pekerjaan Dinding } \\
\text { dan Rangka } \\
\text { bangunan }\end{array}$ & $\mathrm{C}$ & B & 28 \\
\hline 4 & Pekerjaan Plumbing & $\mathrm{D}$ & $\mathrm{C}$ & 12 \\
\hline 5 & $\begin{array}{l}\text { Pekerjaan Instalasi } \\
\text { Listrik }\end{array}$ & $\mathrm{E}$ & $\mathrm{C}$ & 7 \\
\hline 6 & $\begin{array}{l}\text { Pekerjaan Atap dan } \\
\text { Plafond }\end{array}$ & $\mathrm{F}$ & $\mathrm{D}, \mathrm{E}$ & 14 \\
\hline 7 & $\begin{array}{l}\text { Pekerjaan Pintu dan } \\
\text { Jendela }\end{array}$ & G & $\mathrm{F}$ & 12 \\
\hline 8 & $\begin{array}{l}\text { Pekerjaan Finishing } \\
\text { Dinding }\end{array}$ & $\mathrm{H}$ & G & 12 \\
\hline 9 & $\begin{array}{l}\text { Pekerjaan } \\
\text { Pengecatan }\end{array}$ & $\mathrm{I}$ & $\mathrm{H}$ & 7 \\
\hline 10 & Pekerjaan Lantai & $\mathrm{J}$ & $\mathrm{I}$ & 14 \\
\hline 11 & $\begin{array}{l}\text { Pekerjaan Pagar } \\
\text { Pembatas }\end{array}$ & K & $\mathrm{J}$ & 7 \\
\hline 12 & $\begin{array}{l}\text { Pekerjaan Luar } \\
\text { Bangunan }\end{array}$ & $\mathrm{L}$ & $\mathrm{K}$ & 7 \\
\hline
\end{tabular}

mengetahui waktu tercepat terjadinya event (TE) dengan perhitungan sebagai berikut :

$$
\begin{aligned}
& \text { TE } 1=0+\text { durasi }=0+7=7 \\
& \text { TE } 2=\text { TE } 1+\text { durasi }=7+21=28 \\
& \text { TE3 }=\text { TE2 }+ \text { durasi }=28+28=56 \\
& \text { TE } 4=\text { TE } 3+\text { durasi }=56+12=68 \\
& \text { TE5 }=\text { TE } 3+\text { durasi }=56+7=63 \\
& \text { TE6 }=\text { TE } 4+\text { durasi }=68+14=82, \text { TE6 }=\text { TE } \\
& 5+\text { durasi }=63+14=77 \\
& \text { TE } 6=\text { maks }(82 ; 77)=82 \\
& \text { TE7 }=\text { TE6 }+ \text { durasi }=82+12=94 \\
& \text { TE } 8=\text { TE7 }+ \text { durasi }=94+12=106 \\
& \text { TE9 }=\text { TE } 8+\text { durasi }=106+7=113
\end{aligned}
$$


RESISTOR (elektRonika kEndali telekomunikaSI tenaga liSTrik kOmputeR) Vol. 1 No. 2 e-ISSN : 2621-9700, p-ISSN : 2654-2684

$\mathrm{TE} 10=\mathrm{TE} 9+$ durasi $=113+14=127$

TE1 $1=$ TE10 + durasi $=127+7=134$

TE $12=$ TE $11+$ durasi $=134+7=143$

Menentukan perhitungan mundur dengan tujuan untuk menentukan waktu paling lambat dimulainya suatu event dan waktu paling lambat diselesaikannya suatu event yaitu dengan perhitungan sebagai berikut :

TL11 $=$ TE $12-$ durasi $=141-7=134$

TL10 $=$ TE $11-$ durasi $=134-7=127$

TL9 $=$ TE $10-$ durasi $=127-14=113$

TL8 $=$ TL9 - durasi $=113-7=106$

TL7 $=$ TL8 - durasi $=106-12=94$

TL6 $=$ TL7 - durasi $=94-12=82$

TL5 $=$ TL6 - durasi $=82-14=68$

TL4 $=$ TL5 - durasi $82-14=68$

TL3 $=$ TL4 - durasi $=68-12=56$, TL3 $=$ TL4 durasi $=68-7=61$

$\mathrm{TL} 3=\min (56 ; 61)=56$

TL2 $=$ TL3 - durasi $=56-28=28$

$\mathrm{TL} 1=\mathrm{TL} 2-$ durasi $=28-21=7$

TL $0=$ TL $1-$ durasi $=7-7=0$

Selanjutnya tentukan nilai total float $(\mathrm{S})$ dan free float (SF) dengan melakukan perhitungan sebagai berikut

Total Float $(S)=T L(j)-T E(i)-t(i, j)$

Free Float $(S F)=T E(j)-T E(i)-t(i, j)$

AS $=7-0-7=0$

$\mathrm{SF}=7-0-7=0$

$\mathrm{BS}=28-7-21=0$

$\mathrm{SF}=28-7-21=0$

$\mathrm{CS}=56-28-28=0$

$\mathrm{SF}=56-28-28=0$

D $\quad \mathrm{S}=68-56-12=0$

$\mathrm{SF}=68-56-12=0$

$\mathrm{ES}=68-56-7=5$

$\mathrm{SF}=63-56-7=0$

$\mathrm{FS}=82-68-14=0$

$\mathrm{SF}=82-68-14=0$

$\mathrm{GS}=94-82-12=0$

$\mathrm{SF}=94-82-12=0$

$\mathrm{HS}=106-94-12=0$

$\mathrm{SF}=106-94-12=0$

IS $=113-106-7=0$

$\mathrm{SF}=113-106-7=0$

$\mathrm{JS}=127-113-14=0$

$\mathrm{SF}=127-113-14=0$

$\mathrm{KS}=134-127-7=0$

$\mathrm{SF}=134-127-7=0$

$\mathrm{LS}=141-134-7=0$

$\mathrm{SF}=141-134-7=0$ berikut

Sehingga didapat hasil perhitungan sebagai
Tabel 3. Penjadwalan Pengerjaan Proyek Dengan CPM.

\begin{tabular}{|c|c|c|c|c|c|c|c|c|c|c|c|}
\hline \multirow{3}{*}{ wo } & \multirow{3}{*}{ ITEW PECE DUASW } & \multirow{3}{*}{ 10 } & \multirow{3}{*}{$\begin{array}{l}\text { PELDG } \\
\text { HULU }\end{array}$} & \multirow{3}{*}{ 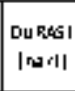 } & \multicolumn{2}{|c|}{ PALING CEPAT } & \multicolumn{2}{|c|}{ PALING LAWNEGT } & \multirow{3}{*}{$\begin{array}{l}\text { TorAL } \\
\text { f wOAT }\end{array}$} & \multirow{3}{*}{$\begin{array}{l}\text { E RE E } \\
\text { E WOATT }\end{array}$} & \\
\hline & & & & & LULA\&I & SELE\&A & WuLAI & SELজ甘: & & & \\
\hline & & & & & ES & EF & تأ & LF & & & \\
\hline 1 & & & & & & & & & & & \\
\hline & & 8 & & $\mathrm{~J}$ & 0 & J & 0 & $\mathrm{~T}$ & 0 & 0 & \\
\hline 2 & 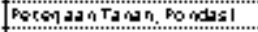 & $\bar{B}$ & $A$ & 21 & $\mathrm{I}$ & 28 & $\mathrm{~J}$ & 28 & 0 & 0 & \\
\hline 3 & 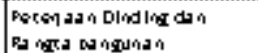 & c & E & 28 & 28 & 56 & 28 & 56 & 0 & 0 & \\
\hline 4 & Pstoldan Plumbling & D & $c$ & 12 & 56 & 68 & 56 & 68 & 0 & 0 & \\
\hline $\mathrm{s}$ & 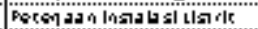 & $\mathbf{E}$ & $c$ & $\mathrm{~T}$ & 56 & 63 & 56 & 68 & $\mathrm{~s}$ & 0 & $\infty$ \\
\hline 6 & Bercolasingaden p batond & $F$ & $\mathrm{DE}$ & 14 & 68 & 82 & 68 & 82 & 0 & 0 & \\
\hline$T$ & 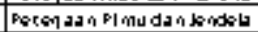 & G & 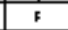 & 12 & 82 & 94 & 82 & 94 & 0 & 0 & \\
\hline 8 & 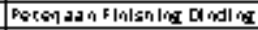 & 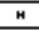 & G & 12 & 34 & 106 & 94 & 106 & 0 & 0 & \\
\hline 9 & 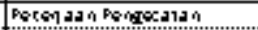 & 1 & H & $T$ & 106 & 112 & 106 & 112 & 0 & 0 & \\
\hline 10 & 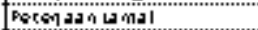 & J & $\mathrm{T}$ & 14 & 123 & 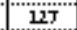 & 113 & $12 T$ & 0 & 0 & \\
\hline 11 & 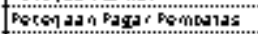 & 5 & 1 & $T$ & $12 T$ & 124 & $12 T$ & 124 & 0 & 0 & \\
\hline 12 & 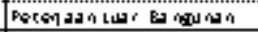 & $\mathrm{t}$ & 5 & $\mathrm{~T}$ & 134 & 141 & 124 & 141 & 0 & 0 & \\
\hline & & & & & & & & & & & \\
\hline
\end{tabular}

Dari tabel di atas dapat di gambarkan jaringan kerja sebagai berikut : 
RESISTOR (elektRonika kEndali telekomunikaSI tenaga liSTrik kOmputeR) Vol. 1 No. 2 e-ISSN : 2621-9700, p-ISSN : 2654-2684

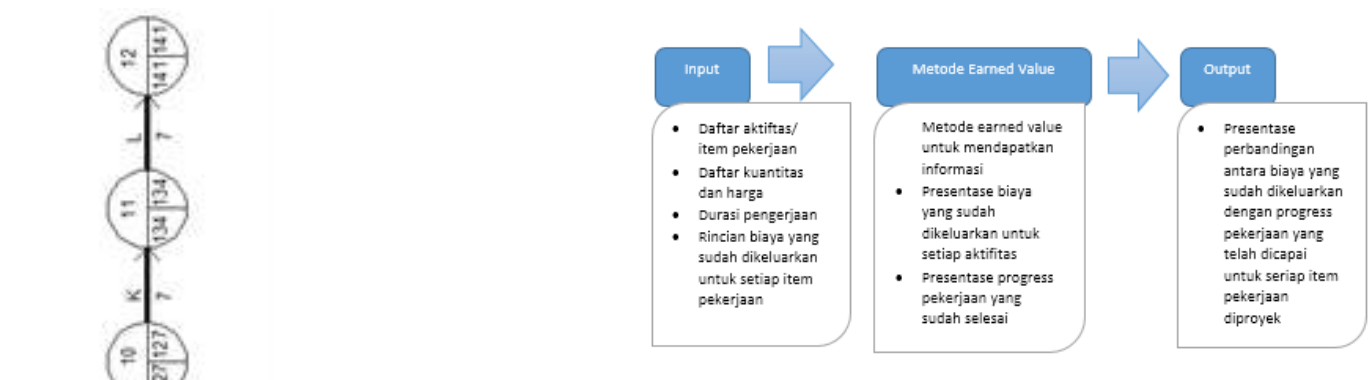

Gambar 10. Konsep Metode Earned Value.

Ada 3 elemen yang dasar yang harus ada dalam penerapan konsep metode Eaned Value yaitu sebagai berikut :

1. Budget Cost forWorks Schedule (BCWS) merupakan anggaran biaya yang dialokasikan berdasarkan rencana kerja yang telah disusun. Data BCWS yang ada adalah sebagai berikut :

Gambar 9. Jaringan kerja tahap dengan CPM.

Dari jaringan kerja di atas dapat di simpulkan Jalur kritis : A, B, C, D, F, G, H, I, J, K, L

Waktu Pelaksanaan

$7+21+28+12+14+12+12+7+14+7+7$

$=141$ hari

Konsep nilai hasil pada pengembangan aplikasi ini secara garis besar dapat dijelaskan sebagai berikut :

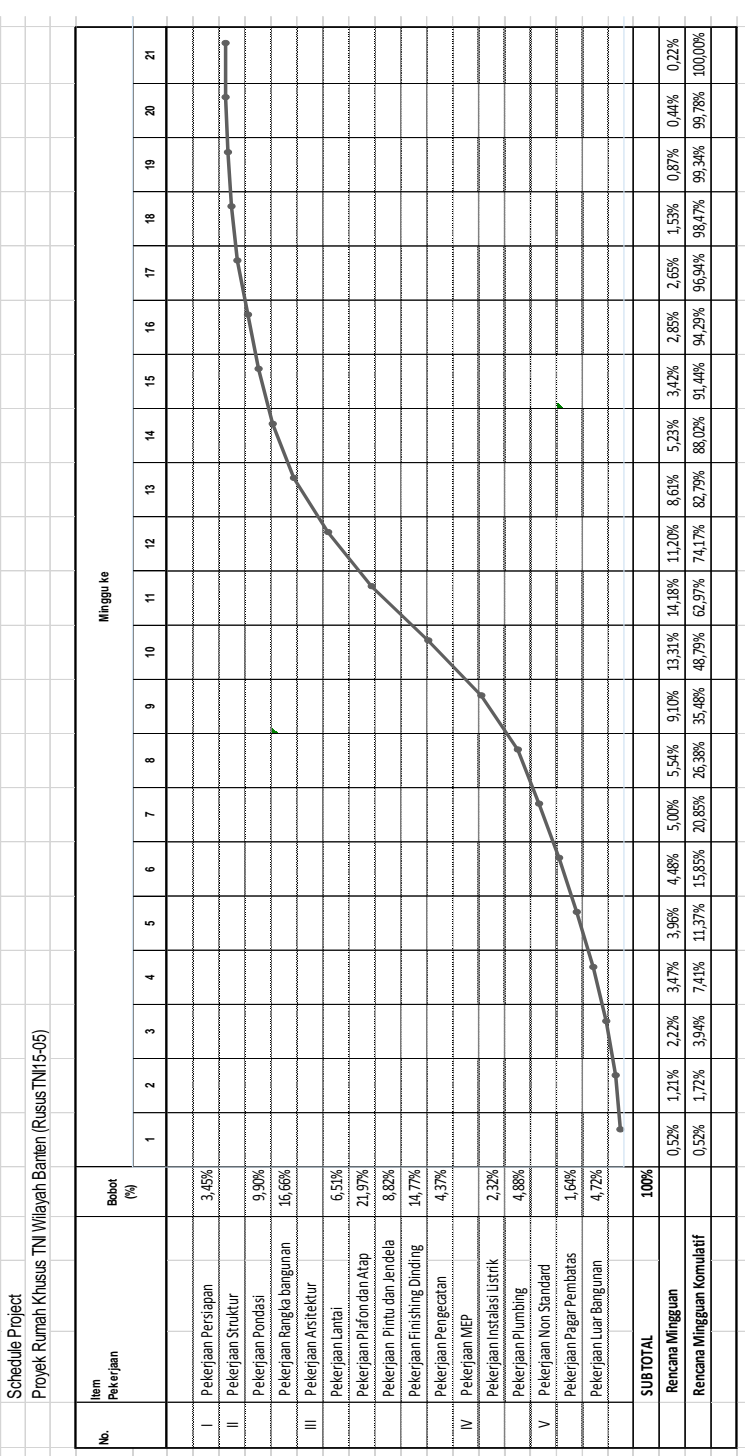

Gambar 11. Data BCWS Proyek. 
RESISTOR (elektRonika kEndali telekomunikaSI tenaga liSTrik kOmputeR) Vol. 1 No. 2 e-ISSN : 2621-9700, p-ISSN : 2654-2684

2. Budget Cost forWorks Performed (BCWP) merupakan nilai yang diterima dari penyelesaian pekerjaan selama periode waktu tertentu. Data BCWP yang ada adalah sebagai berikut :
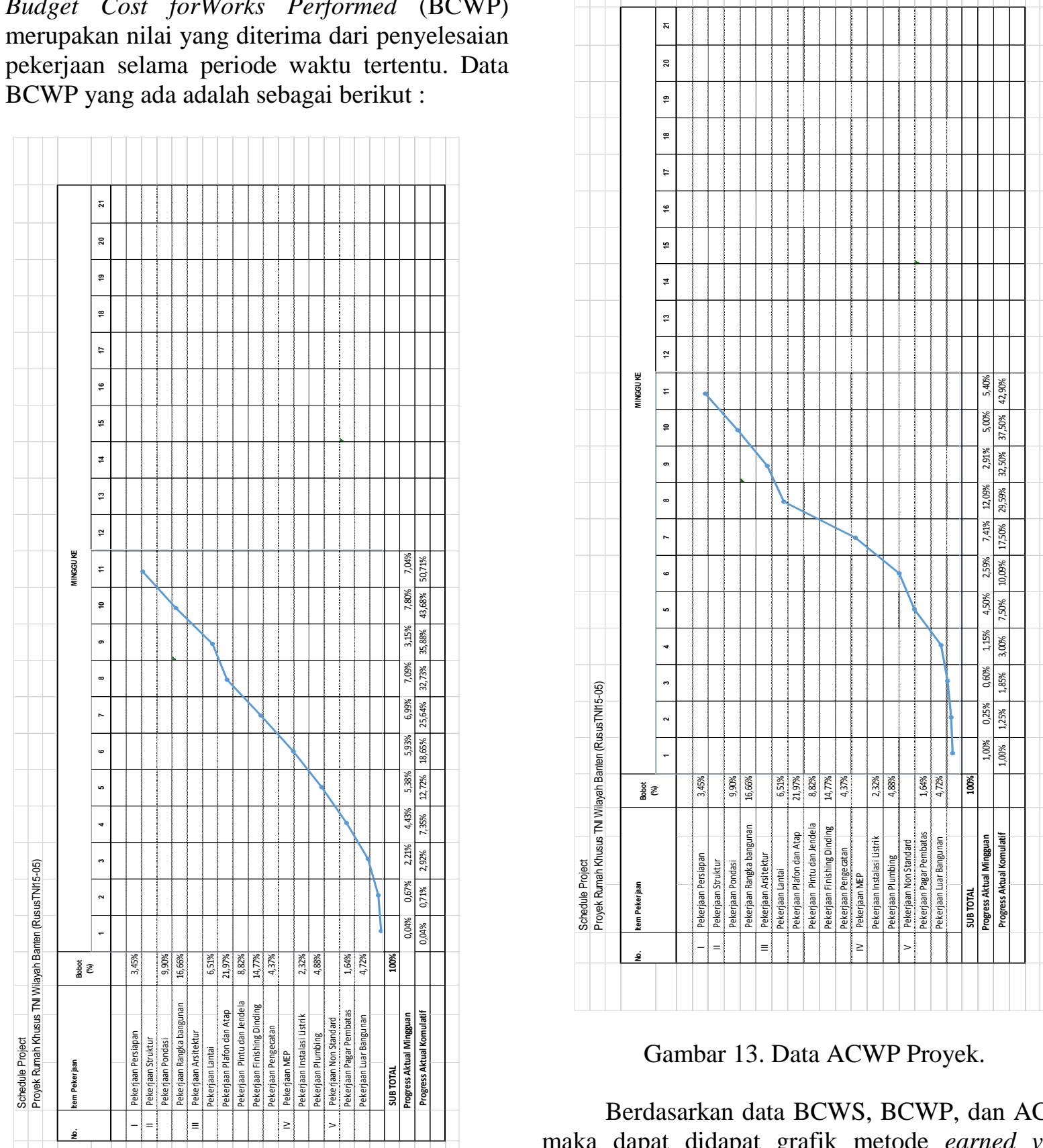

\section{Gambar 13. Data ACWP Proyek.}

Berdasarkan data BCWS, BCWP, dan ACWP maka dapat didapat grafik metode earned value yaitu sebagai berikut

Gambar 12. Data BCWP Proyek.

3. Cost forWorks Performed (ACWP) merupakan presentase seluruh pengeluaran proyek selama periode waktu tertentu. Adapun data ACWP yang ada adalah sebagai berikut : 
RESISTOR (elektRonika kEndali telekomunikaSI tenaga liSTrik kOmputeR) Vol. 1 No. 2 e-ISSN : 2621-9700, p-ISSN : 2654-2684

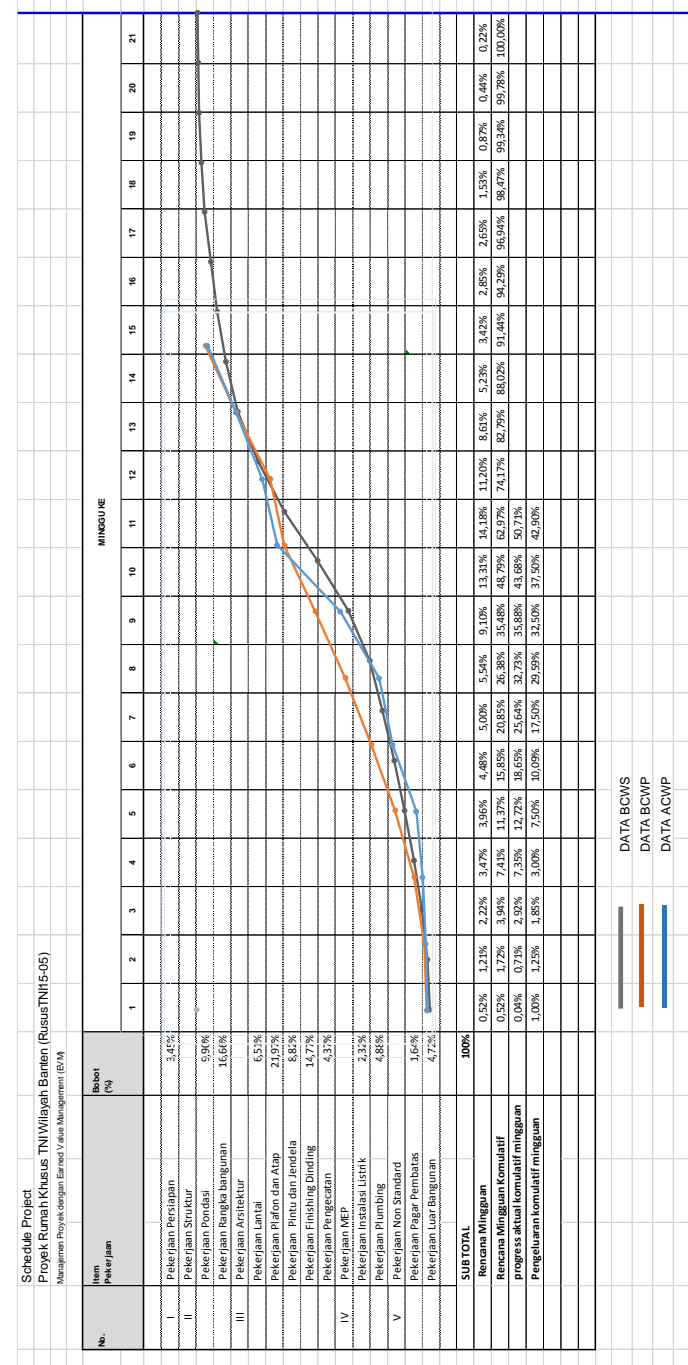

Gambar 14. Grafik dengan Proyek dengan EVM.

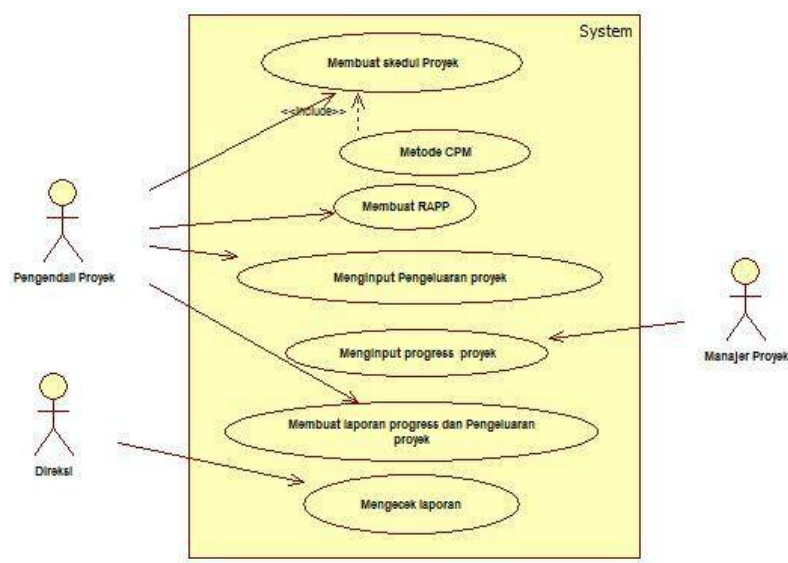

Gambar 15. Use case diagram sistem usulan.
Berdasarkan use case diagram di atas dapat digambar activity diagram sistem usulan yaitu sebagai berikut :

1. Pengendali proyek

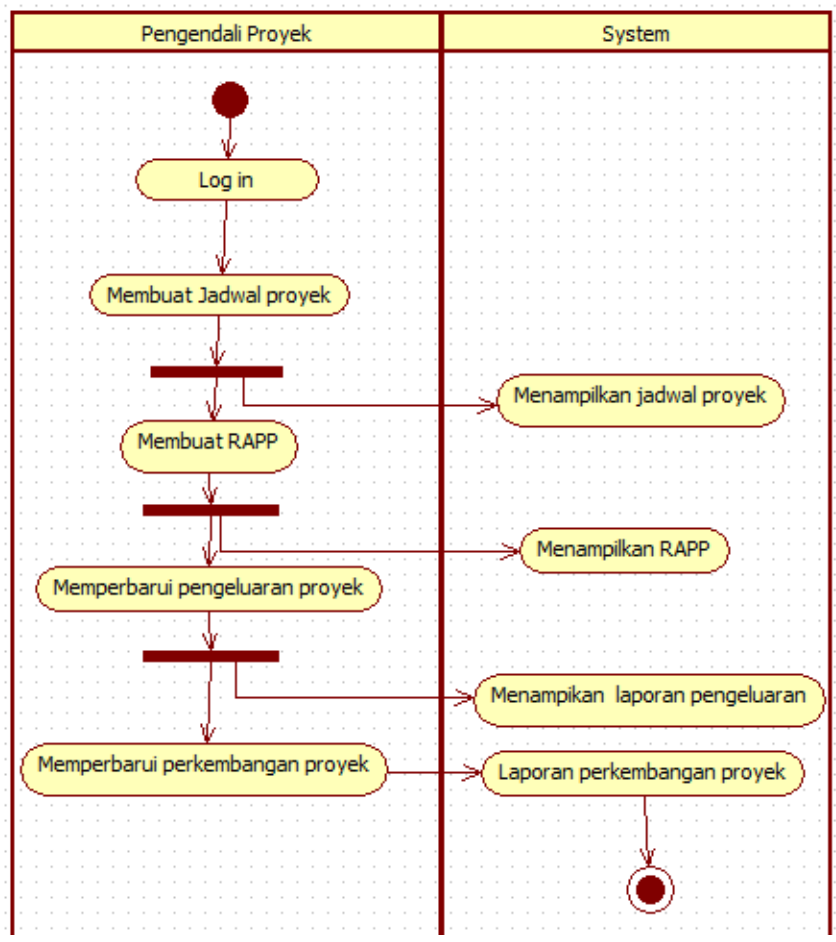

Gambar 16. Diagram activity Pengendali Proyek.

2. Manajer Proyek

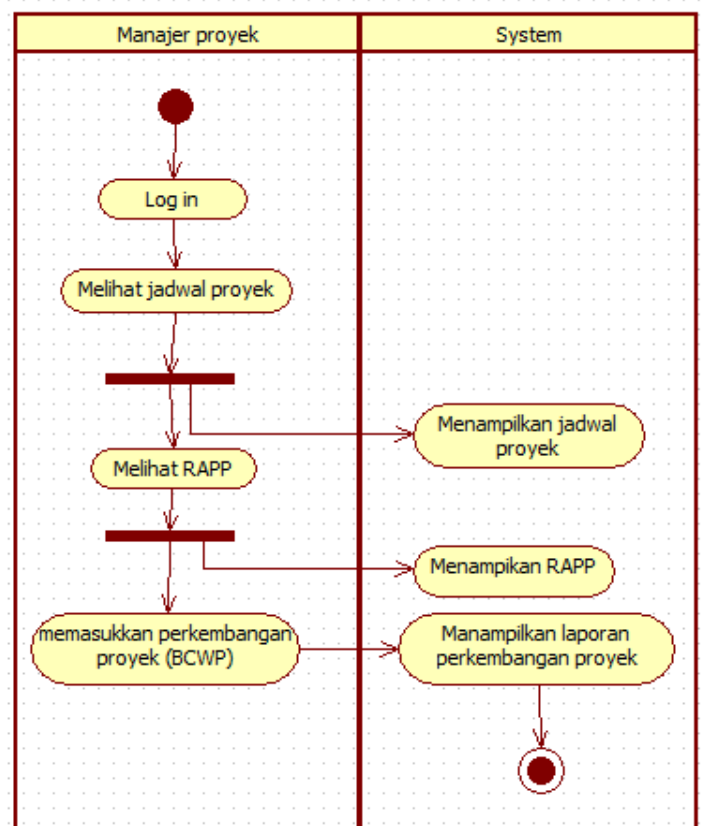

Gambar 17. Diagram activity Manajer Proyek. 
RESISTOR (elektRonika kEndali telekomunikaSI tenaga liSTrik kOmputeR) Vol. 1 No. 2 e-ISSN : 2621-9700, p-ISSN : 2654-2684

3. Direksi

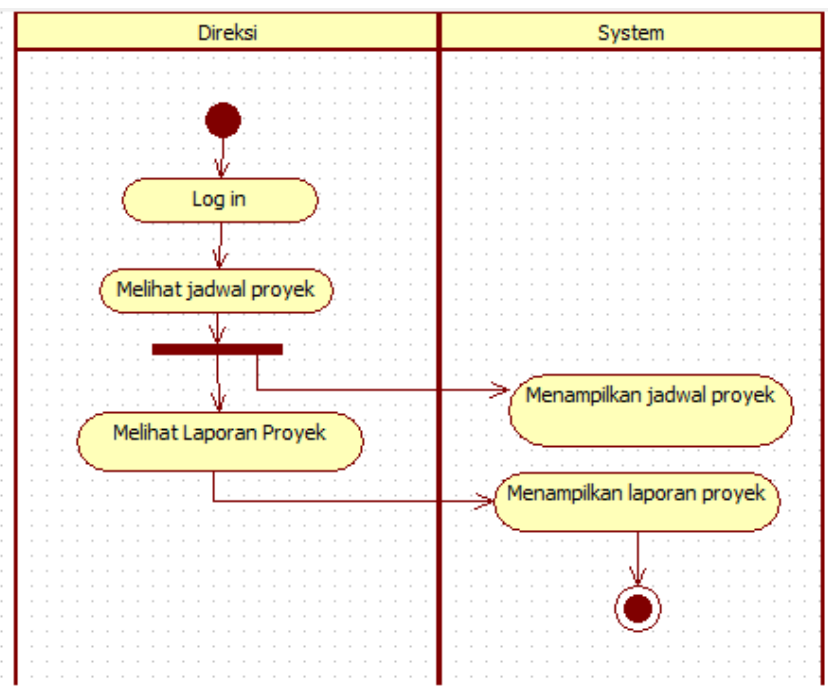

Gambar 18. Diagram activity sistem usulan 3.

Perancangan basis data pada sistem manajemen proyek ini dapat dijelaskan dengan Entity Relantionship Diagram (ERD) yaitu sebagai berikut :

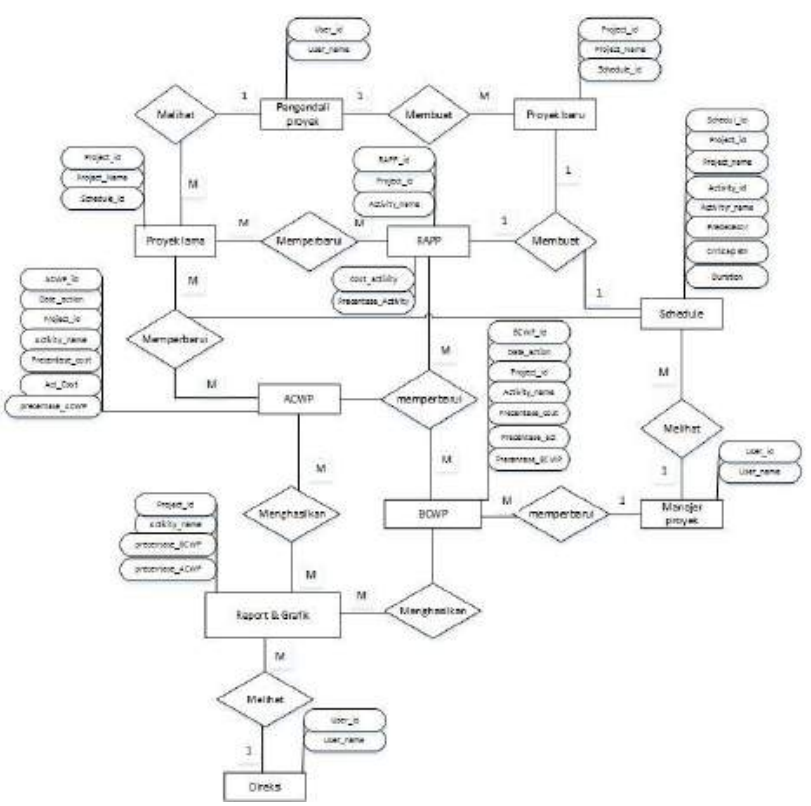

Gambar 19. ERD Sistem Manajement Proyek.

Pada Perancangan proses ini akan digambarkan dengan Hierarchy Input Process Output (HIPO).

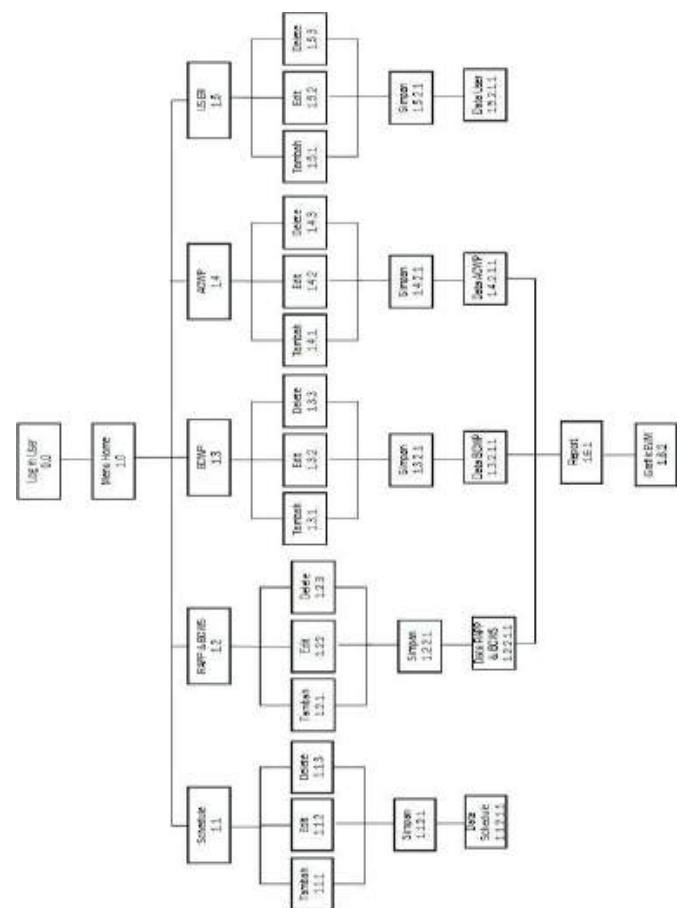

Gambar 20. Hierarchy Input Process Output (HIPO).

\section{HASIL DAN PEMBAHASAN}

Di sini akan dibahas hasil dan pembahasan 1. Flowchart Log In dan Log Out

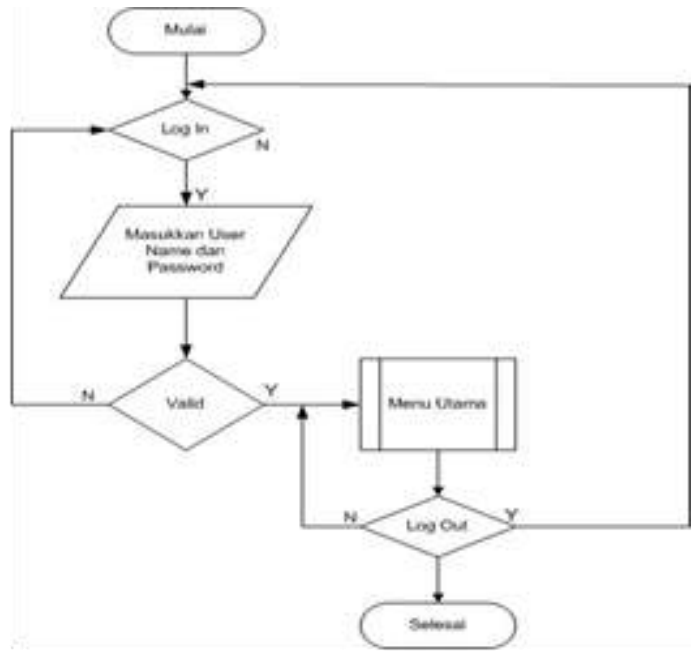

Gambar 21. Flowchart Log in. 
RESISTOR (elektRonika kEndali telekomunikaSI tenaga liSTrik kOmputeR) Vol. 1 No. 2 e-ISSN : 2621-9700, p-ISSN : 2654-2684

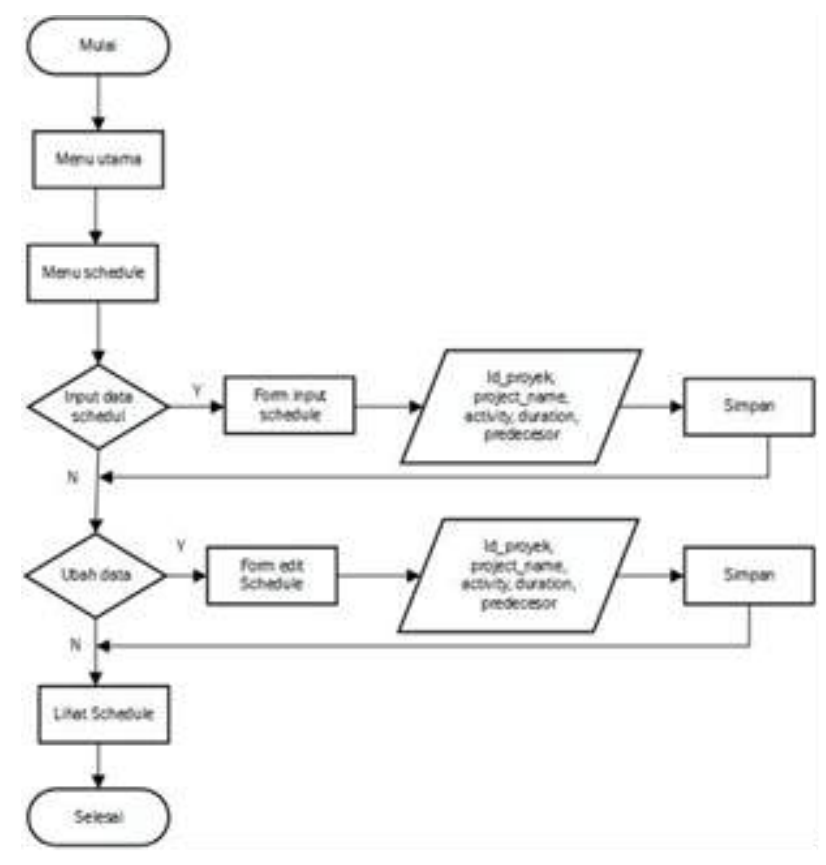

Gambar 22. Flowchart Schedule.

3. Flowchart BCWS

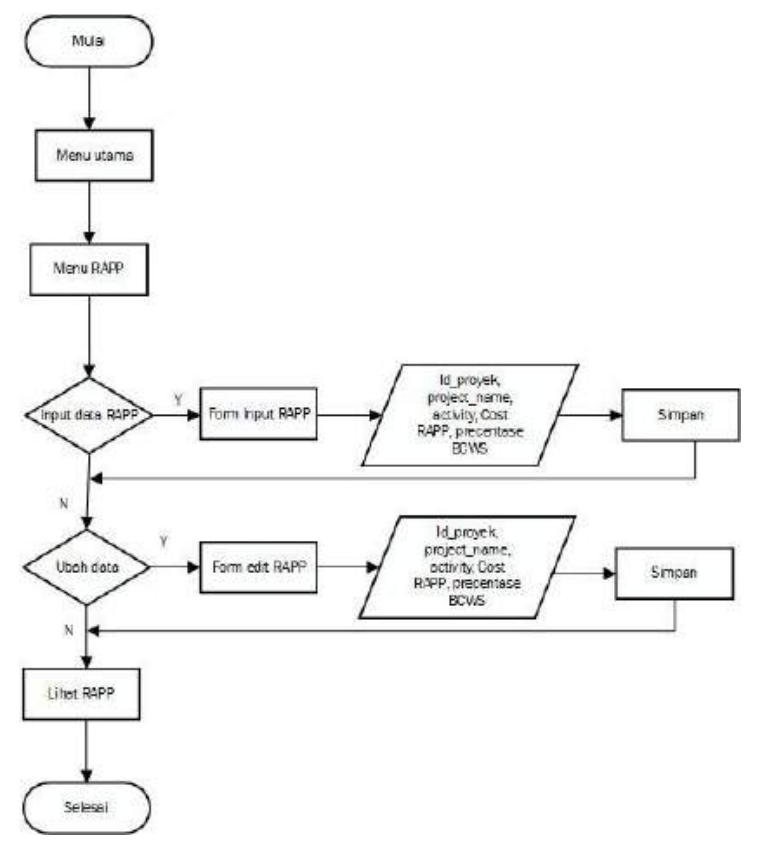

Gambar 23. Flowchart BCWS.

4. Flowchart BCWP

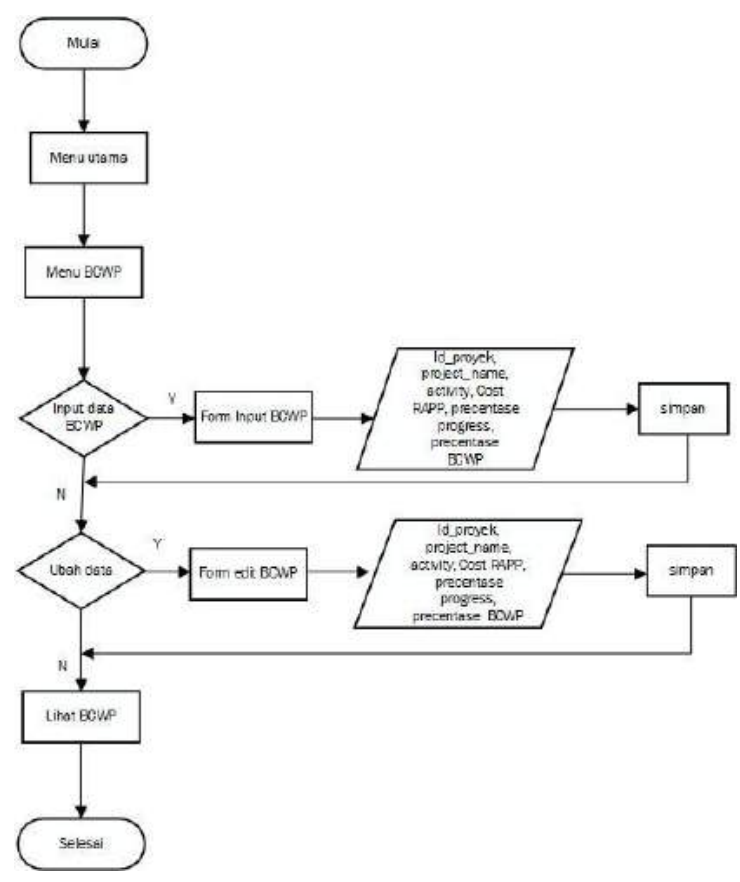

Gambar 24. Flowchart BCWP.

5. Flowchart ACWP

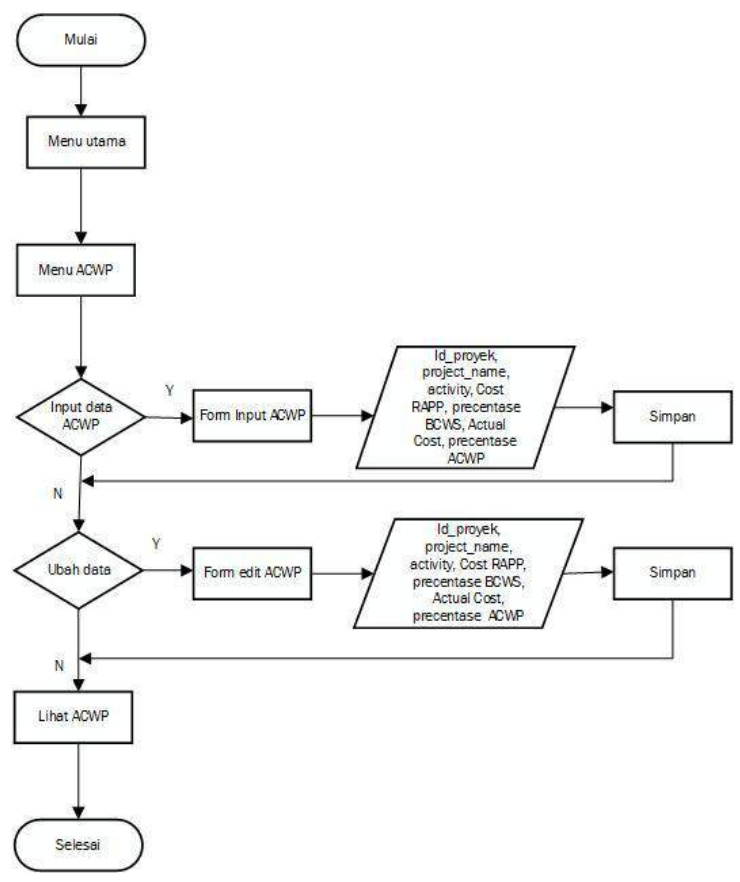

Gambar 25. Flowchart ACWP.

6. Flowchart Report 
RESISTOR (elektRonika kEndali telekomunikaSI tenaga liSTrik kOmputeR) Vol. 1 No. 2 e-ISSN : 2621-9700, p-ISSN : 2654-2684

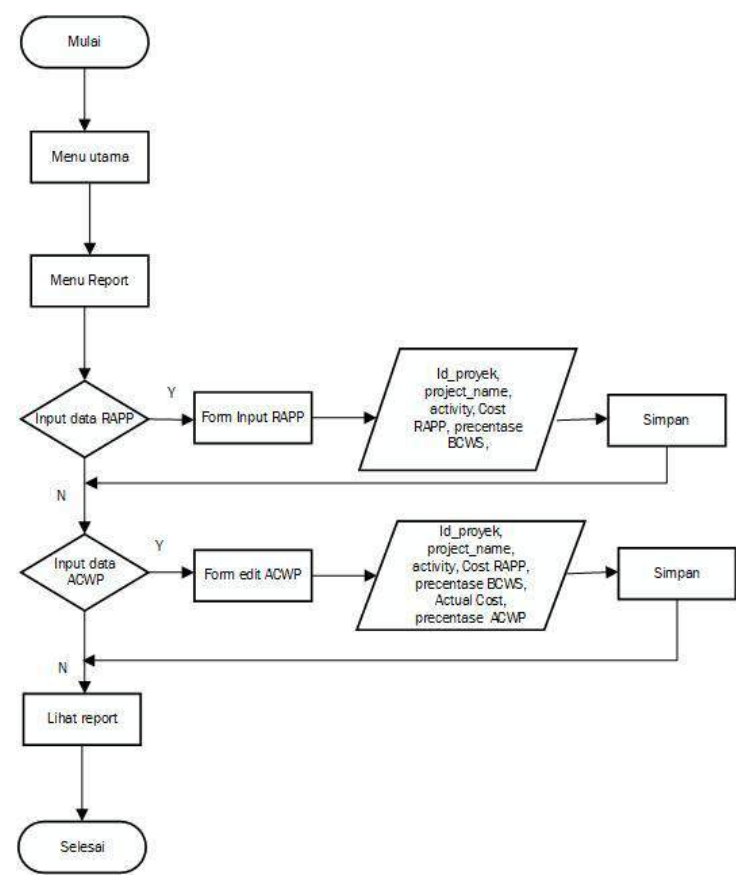

Gambar 26. Flowchart Report.

7. Flowchart User

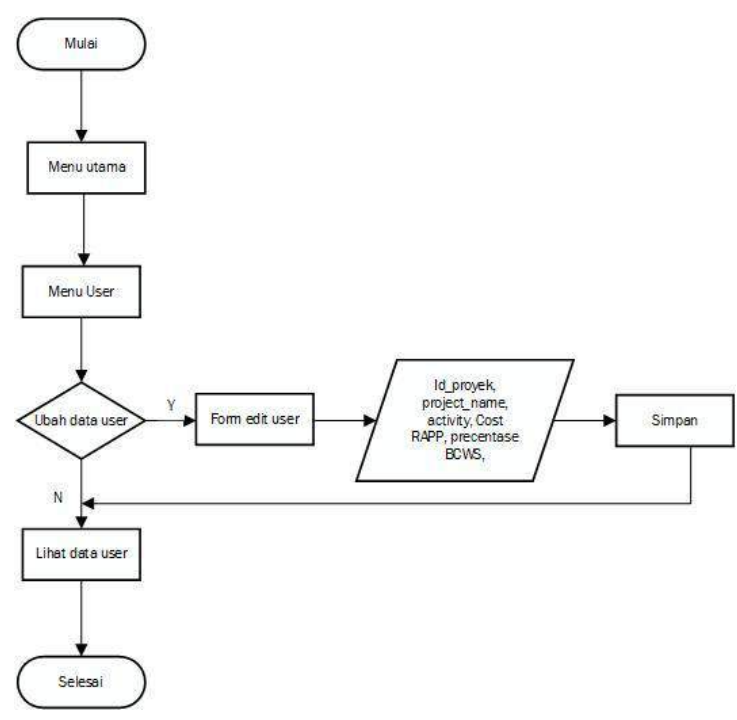

Gambar 27. Flowchart User.

8. Flowchart Grafik EVM

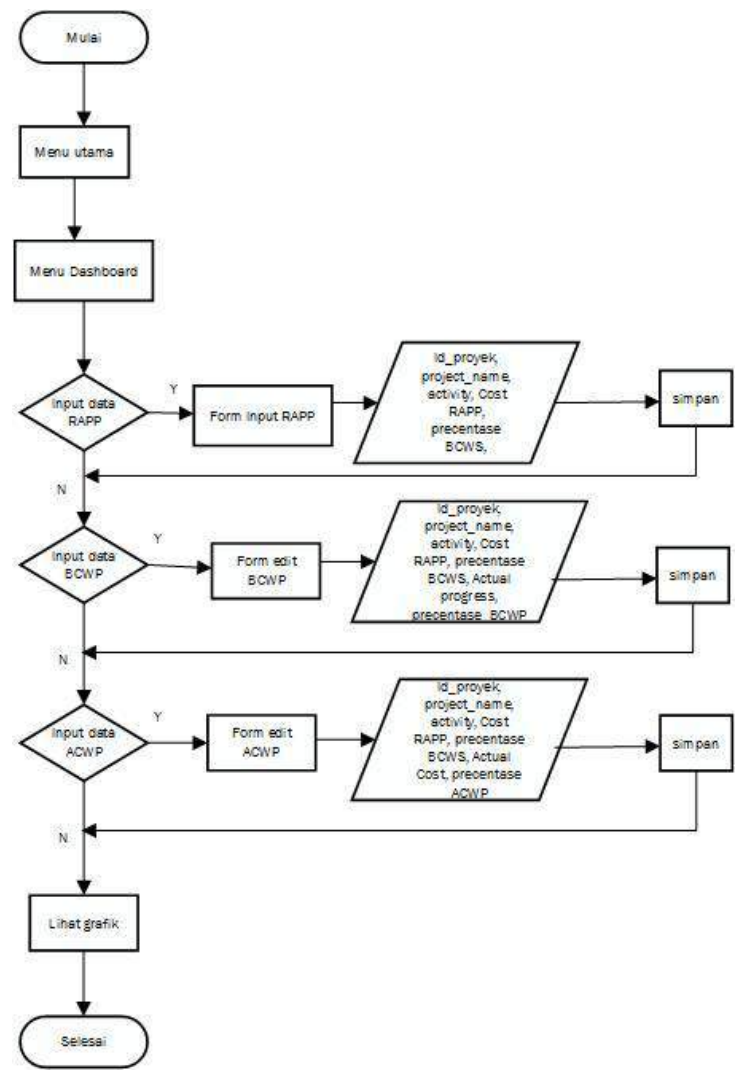

Gambar 28. Flowchart Grafik EVM.

Tabel 4. Pengujian sistem.

\begin{tabular}{|l|l|l|l|l|}
\hline No & $\begin{array}{l}\text { Fungs } \\
\text { i }\end{array}$ & Metode & Hasil Test & $\begin{array}{l}\text { Kesimpul } \\
\text { an }\end{array}$ \\
\hline 1. & Log in & Input data & $\begin{array}{l}\text { Masuk ke dalam } \\
\text { sistem jika } \\
\text { benar dan } \\
\text { Menampilkan } \\
\text { "log in anda } \\
\text { gagal user name } \\
\text { atau passwod } \\
\text { salah “jika } \\
\text { salah }\end{array}$ & Berfungsi \\
\hline 2. & $\begin{array}{l}\text { Sched } \\
\text { ule }\end{array}$ & Input data & $\begin{array}{l}\text { Data berhasill } \\
\text { disimpan, jika } \\
\text { tidak akan } \\
\text { tampil } \\
\text { "Data Schedule } \\
\text { tidak lengkap “ } \\
\text { atau } \\
\text { "Data Schedule } \\
\text { sudah ada“ }\end{array}$ & Berfungsi \\
\hline 3. & RAPP & Input data & $\begin{array}{l}\text { Data berhasill } \\
\text { disimpan, jika } \\
\text { tidak akan }\end{array}$ & Berfungsi \\
\hline
\end{tabular}


RESISTOR (elektRonika kEndali telekomunikaSI tenaga liSTrik kOmputeR) Vol. 1 No. 2 e-ISSN : 2621-9700, p-ISSN : 2654-2684

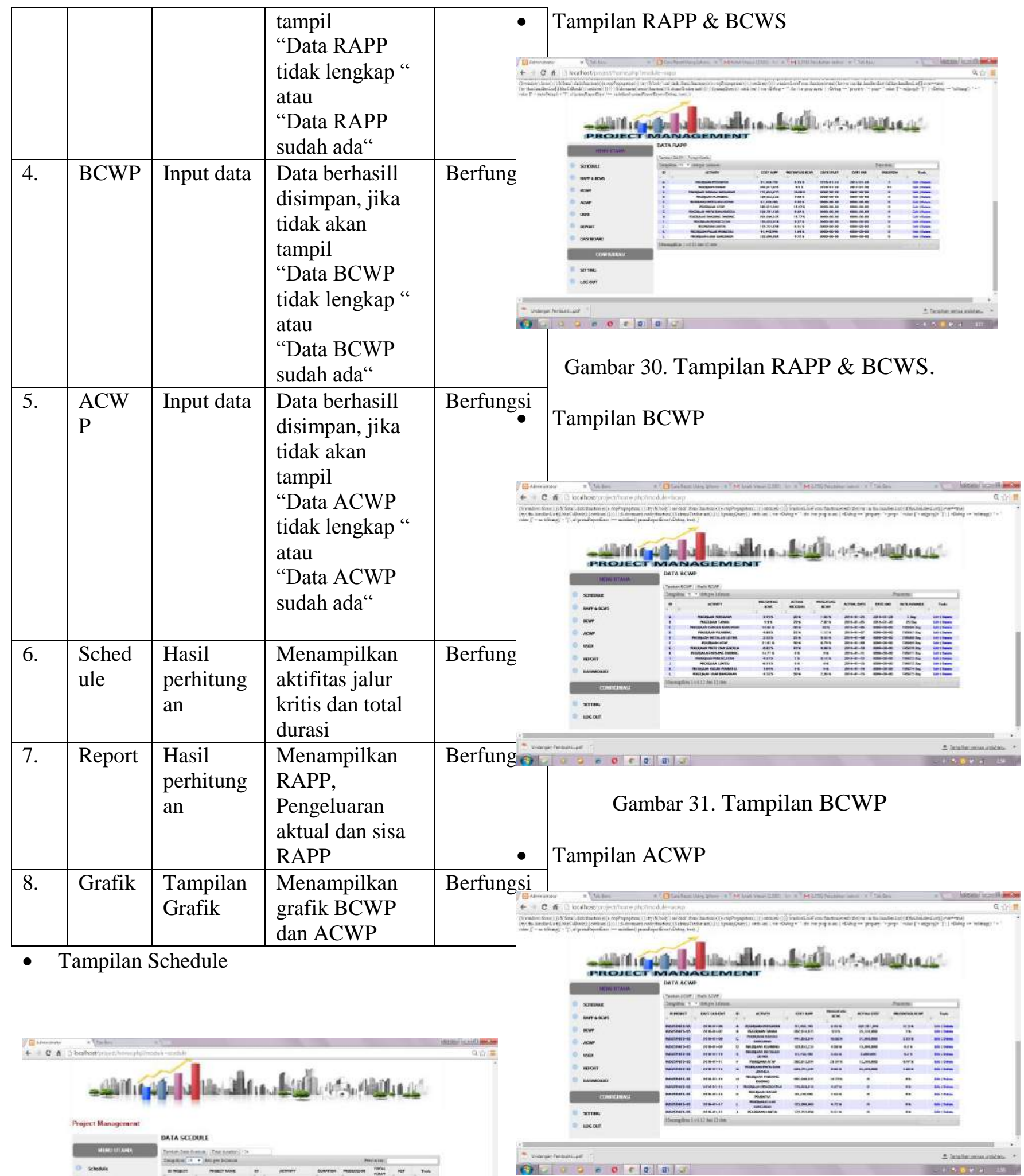

Gambar 32. Tampilan Menu ACWP.

- Tampilan Report

Gambar 29. Tampilan menu schedule. 
RESISTOR (elektRonika kEndali telekomunikaSI tenaga liSTrik kOmputeR) Vol. 1 No. 2 e-ISSN : 2621-9700, p-ISSN : 2654-2684

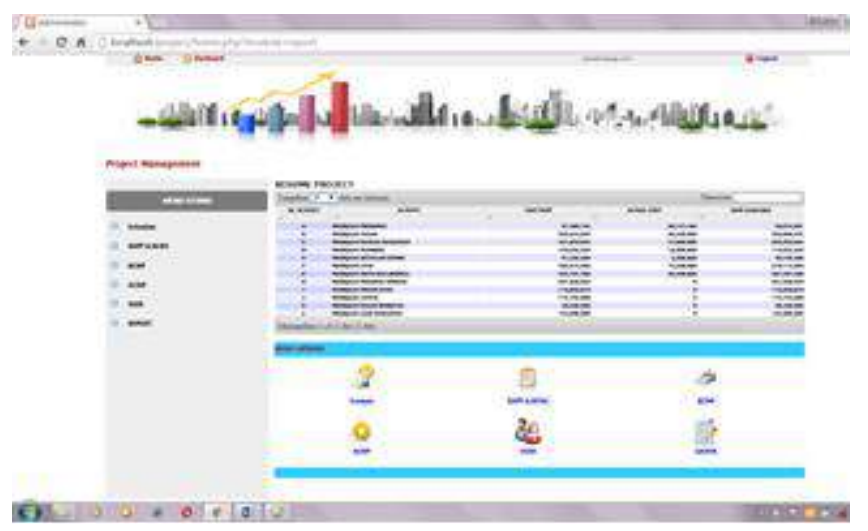

Gambar 33. Tampilan menu report.

- Tampilan Grafik

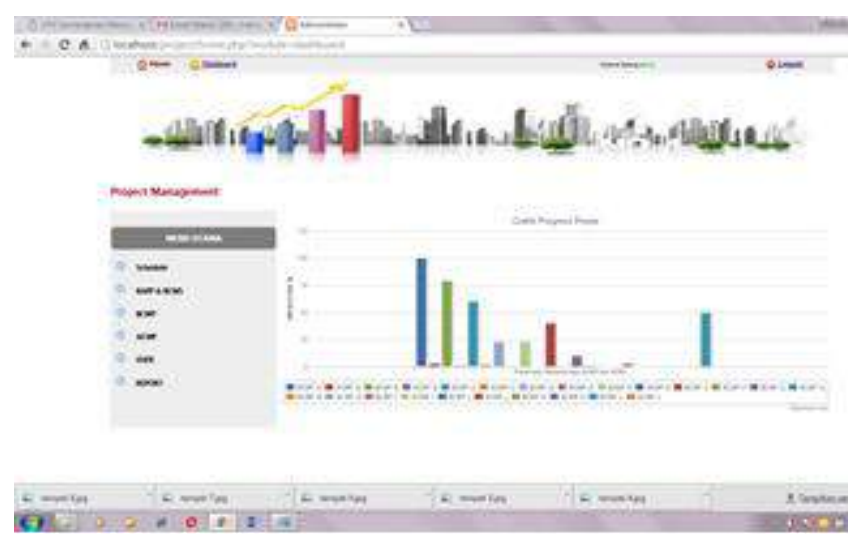

Gambar 34. Tampilan menu grafik.

\section{KESIMPULAN DAN SARAN}

Kesimpulan dari perancangan sistem aplikasi manajemen proyek dengan menggunakan metode critical path dan earned value management adalah sebagai berikut:

1. Sistem manajemen proyek ini dapat menampilkan informasi mengenai aktifitas aktifitas yang berada dijalur kritis sehingga perlu diperhatikan lebih teliti.

2. Sistem aplikasi ini dapat ketahui total durasi waktu pengerjaan proyek yang lebih efektif.

3. Sistem aplikasi dapat berfungsi untuk memperbarui data perkembangan proyek setiap waktu dan dimana saja.

4. Melalui sistem aplikasi ini pengendali proyek dapat memperbarui data Pengeluaran proyek setiap waktu dan dimana saja.

5. Sistem aplikasi ini dapat memantau kondisi suatu proyek yang dapat dilihat dari perkembangan proyek dan total pengeluaran proyek sehingga dapat dketahui lebih dini jika terjadi over bugdet maupun untuk mengetahui prediksi laba atau rugi.
6. Melalui sistem aplikasi ini para direksi dapat memantau perkembangan proyek dan pengeluaran proyek secara online.

Tampilan dibuat lebih menarik dan lebih mudah dipahami (user firendly)

\section{DAFTAR PUSTAKA}

[1] H. Abror, Manajemen Proyek. Serpong: ANDI, 2008.

[2] A. Kadir, Pengenalan Sistem Informasi. Yogyakarta: Andi Publisher, 2002.

[3] R. S. Pressman, Rekayasa Perangkat Lunak, Pendekatan Praktisi Buku. Andi Publisher, 2002.

[4] D. S. Tiyas, "REKAYASA PERANGKAT LUNAK PENDUKUNG KEPUTUSAN PENENTUAN SUPPLIER DENGAN MENGGUNAKAN METODE PROFILE MATCHING PADA UD GUNUNG MAS SEMARANG," Universitas Dian Nuswantoro, p. 8 .

[5] A. Nugroho, Rekayasa Perangkat Lunak Menggunakan UML dan Java. Yogyakarta: Andi Publisher, 2009.

[6] I. Raharja, "ANALISA PENJADWALAN PROYEK DENGAN METODE PERT DI PT. HASANA DAMAI PUTRA YOGYAKARTA PADA PROYEK PERUMAHAN TIRTA SANI," Jurnal Bentang, vol. 2, no. 1, p. 14, 2014.

[7] K. Kinkinzaen, 2004.

[8] S. Soemardi, 2007. 